\title{
About Prospects of Participation of Russia in the Convention on the International order of Alimony Recovering of 2007
}

\author{
Zamira Asrarovna Akhmetyanova ${ }^{1}$, Olga Nikolaevna Nizamieva ${ }^{1} \&$ Inna Igorevna Novikova $^{1}$ \\ ${ }^{1}$ Kazan Federal University, Russia \\ Correspondence: Zamira Asrarovna Akhmetyanova, Kazan Federal University, Russia. E-mail: \\ zamira9@yandex.ru
}

Received: June 9, 2019

Accepted: August 25, $2019 \quad$ Online Published: August 31, 2019

doi:10.5539/jpl.v12n5p25

URL: https://doi.org/10.5539/jpl.v12n5p25

\begin{abstract}
The article analyzes the prospects for the possible participation of the Russian Federation in the Convention on the International order of alimony recovering and Other Forms of Family Maintenance in 2007. Identified factors contributing to the ratification of the Convention, as well as circumstances that create certain difficulties. Among the first are: universality of the Convention; compliance of many provisions of the Convention with the norms of family, civil procedural legislation and legislation on enforcement proceedings of the Russian Federation; the existence of a real mechanism that facilitates the effective alimony recovering abroad, and thereby satisfies the vital needs of needy family members. Among the factors of a "restraining nature", some differences were noted in the provisions of the Convention and Russian legislation regarding entities entitled to alimony. In addition, Russia's accession to the Convention may require a review of national legislation on the provision of free legal aid. However, the system of reservations and declarations of amendment or cancellation of the rules provided for in the Convention allows to mitigate the constraints. As a result, it was concluded that for the Russian Federation, ratification of this Convention will have a greater effect and will solve the problem of receiving alimony from abroad.
\end{abstract}

Keywords: alimony, maintenance relations with a foreign element, child right to upkeep, forced collection of alimony, 2007 Convention on the International Collection of Alimony

\section{Introduction}

UN Convention on the Rights of the Child in Art. 27 secures the right of every child to the standard of living necessary for the physical, mental, spiritual, moral and social development of the child, and the obligation of parents (or other persons raising a child) to provide the child with such living conditions within their abilities and financial capabilities. States parties to the Convention, in accordance with national conditions and within their capabilities, should take the necessary measures to assist parents and other children raising children in exercising this right, and, if necessary, provide material assistance and support programs, especially with regard to providing the child with food, clothing and housing. If it is necessary to ensure the restoration of the maintenance of the child by parents or other persons who are financially responsible for the child, then the participating states should take all necessary measures both within the state and from abroad.

Note that the Family Code of the Russian Federation provides a rule on the right of the child to receive maintenance from their parents and other family members. Russian law provides a system of legal means aimed at the realization of this right, starting from the establishment of variability in determining the forms, size, methods, procedures and other parameters for the provision of content (given the presence or absence of conflict between family members, as well as other individual life circumstances) and ending with measures, ensuring the receipt of maintenance and establishing responsibility for the improper performance of duties.

If the child and the person obligated to support the child live in different states, then the states parties to the above-mentioned Convention on the Rights of the Child should facilitate accession to or the conclusion of international agreements, as well as the achievement of other relevant agreements. Since at the same time relations on the maintenance of the child and its provision fall under the regulation of the national legislation of different states, and also become the subject of international legal regulation, the realization of the child's right to support by alimony recovering from a parent living in another state often encounters certain difficulties. 
In order to solve the problems and conflicts arising in this case, the Hague adopted in 2007 a special Convention on the International order of alimony recovering for Children and Other Forms of the Family support, some analysis of which, along with an attempt to assess the prospects for ratification of this treaty by the Russian Federation, is supposed in this work.

\section{Methods}

In the research process, comparative legal and sociological methods, methods of legal modeling and forecasting, and a legal interpretation method were used.

\section{Results and discussion}

The Convention on the International order of alimony recovering for Children and Other Forms of the Family Adopted at the Twenty-First Session of the Hague Conference on Private International Law (hereinafter referred to as the 2007 Convention) essentially replaced the 1956 UN Convention on the alimony recovering abroad, and also two Hague Conventions - on the recognition and enforcement of decisions in the area of maintenance obligations for children in 1958; on the recognition and enforcement of decisions on maintenance obligations, 1973. The main goal of the developers of the 2007 Convention was to create a unified and harmonized international mechanism for the alimony recovering, which would take into account the problems and shortcomings of the conventions in force at that time, the experience of their application, as well as the possibility of using new information technologies.

Today, 44 states are parties to the 2007 Convention. Russia does not participate in it, but shows interest, as the draft federal law prepared by the Ministry of Justice of Russia on December 5, 2016 may testify.

The value of the 2007 Convention lies in the fact that it provides an effective mechanism for the recovery of alimony when finding an obligated family member in the territory of another state. At the current level of convention regulation, a system of interaction between the authorities of the participating states has been created, a facilitated procedure for submitting applications for the alimony recovering has been provided, recognition and enforcement of decisions and agreements on alimony have been ensured, and appropriate measures have been enshrined for their immediate enforcement.

When deciding on Russia's accession to the Convention, various factors should be kept in mind: the "popularity" of the Convention, the number of countries participating in it, the desirability of strengthening cooperation with these countries; the legal status in these countries of Russian citizens, improving in the presence of an international treaty; the breadth of family relations in the provisions of the Convention; the compliance of the provisions of the international treaty with the norms of Russian law and other circumstances.

According to the Convention, recognition and enforcement are subject to both acts of the judicial authorities (Art. 20) and agreements on the payment of alimony (Art. 30). Family law of the Russian Federation implies the occurrence of an alimentary obligation on the basis of a court decision or conclusion of an alimony agreement. The agreement on the payment of alimony, along with the court decision, is named among executive documents in the legislation on enforcement proceedings. And in this part, one can observe the conformity of conventional and intra-national norms. However, the Civil Procedure Code of the Russian Federation (hereinafter - the Code of Civil Procedure of the Russian Federation) and the existing international treaties of Russia do not contain provisions on the enforcement of agreements concluded on the territory of another state. In this regard, there are two possible solutions to the issue: 1) a change in internal procedural legislation; 2) the use of provided for in paragraph 8 of Article 30 of the Convention, the rights of States parties not to recognize and not to enforce child support agreements. Thus, Belarus, Ukraine, Brazil, and Turkey, when ratifying the Convention, took advantage of this provision and reserved the right not to recognize and not to fulfill the agreement on the payment of alimony.

Under the Convention, a person who has not reached the age of 21 years has the right to receive alimony from parents (Art. 2). However, the legal systems of a number of states, including Russia, provide for duties of parents to maintain minor children, that is, until they reach the age of 18 . To resolve such contradictions and increase the number of parties to the Convention, in the case when, while supporting the Convention as a whole, the state party considers this or that separate provision unacceptable to itself, the creators provided for a system of reservations and declarations. Reservations may be made to specific provisions of the Convention or to the Convention as a whole in certain aspects and do not require recognition by other parties.

So, paragraph 2 of Art 2 of the Convention allows the State party to limit the application of the Convention to persons under the age of 18 , and paragraph 3 of article 2 permits a statement to be made expanding the scope of the Convention. Some States parties to the Convention have seized the opportunity. So, Belarus, Ukraine, Montenegro have limited the age of persons entitled to receive alimony with a bar of 18 years. At the same time, Norway stipulated that it undertakes to enforce decisions on the payment of alimony in favor of children older than 21 years 
old, but not older than 25 years old, while retaining the right not to stipulate the maintenance of children after 21 years. The Republic of Albania has declared its right to ensure fulfillment of obligations to support even adult children under the age of 25 years, provided that they attend secondary school or university.

It seems that if Russia ratified the Convention, a clause on limiting the age of 18 would correspond to the Family Code of the Russian Federation, because the obligation of parents to maintain adult children arises only if the latter are incapable of work.

With regard to expanding the limits of application of the Convention and its extension not only to parent-child relations, but also to relations involving other family members, the Treaty allows the State party to make a corresponding statement (paragraph 3 of Art. 2). For example, Norway has committed to recognize and enforce decisions regarding the maintenance of spouses, to the same extent as decisions regarding the maintenance of children, also applying chapters II and III of the Convention. Upon ratification of the Convention, Ukraine made a statement on the extension of Chapters V and VIII of the Convention to alimony obligations of other family members (in relation to disabled parents, adult disabled children and adult children continuing education, as well as to obligations between grandparents and grandchildren, brothers and sisters, stepmother / stepfather and stepdaughter / stepson). It should be noted that such a statement gives rise to obligations between the participating states only on the condition that both states have made statements about the same types of maintenance obligations and articles of the Convention.

Since the RF IC provides for the existence of maintenance obligations of spouses and other family members, when Russia joins the 2007 Convention, it is advisable to make a statement on extending its effect to maintenance obligations with the participation of these persons, at least in terms of the application of Chapter $\mathrm{V}$ of the Convention (recognition and enforcement).

The Convention provides for conditions under which a decision made in the State of origin must be recognized and enforced by other States Parties. In particular, paragraph 2 of Art. 20 of the Convention relates to the conditions of application of the jurisdiction of the state of origin: a) the relationship of the defendant with the state of origin (place of residence), b) either the presence of a place of residence in the state of origin of the child (subject to co-existence with the defendant, or his provision). At the same time, the state may make a reservation and refuse to recognize the decisions of the state of origin if: c) the creditor resided in the state of origin at the time of the commencement of the proceedings; e) between the parties there is a written agreement on the choice of jurisdiction, with the exception of cases regarding maintenance obligations for the child; $f$ ) the decision was made by the authority whose jurisdiction acted in matters of the civil legal personality of the person or parental responsibility, if the specified jurisdiction was not justified solely by the citizenship of one of the parties. Of the 42 countries for which the Convention has entered into force today, only the United States has made such a reservation in full. Brazil, for example, has declared a reservation to paragraphs. "E" paragraph 2 of article 20 of the Convention that does not recognize and does not enforce the decision, in which the parties reached a written agreement on jurisdiction, when the trial involves obligations to ensure the maintenance of children or persons considered to be disabled by adults and the elderly.

According to paragraph 2 of Art. 402 Code of Civil Procedure of the Russian Federation if the defendant has a place of residence in Russia, then the case should be considered in a Russian court. Also, Russian courts have the right to consider the case if the plaintiff in the case of the recovery of alimony has a place of residence in Russia (paragraph 3 of Art. 402 Code of Civil Procedure of the Russian Federation). Thus, we can conclude that the mandatory provisions of the Convention comply with the current legislation of Russia. Moreover, Art. 404 Code of Civil Procedure of the Russian Federation allows you to establish contractual jurisdiction in cases related to maintenance relations. Consequently, Russia may not enter a reservation not to apply the rule of paragraphs. "E" paragraph 2 of article 20 of the Convention. Regarding paragraphs " $\mathrm{C}$ " of the said article, it seems that a reservation should be introduced upon ratification, because according to the general rules of the Code of Civil Procedure of the Russian Federation, the jurisdiction of cases involving foreign citizens is determined by the place of residence of the defendant and / or the child.

One of the most difficult issues for Russia to accede to the Convention is the issue of providing free legal assistance. According to the Article 15 of the Convention, the state to which the request was sent must provide free legal assistance in respect of all applications submitted by the creditor under the relevant chapter on maintenance obligations arising from the parent-child relationship, in favor of a person under 21 years of age. An exception in accordance with paragraph 2 of Art. 15 is the case when the state considers the statement or complaint to be manifestly ill-founded. Participating countries can also make a statement on the provision of free assistance only after checking the financial situation of the child (Art. 16). 
However, under Russian law, the circle of persons entitled to provide legal assistance, including on issues of alimony recovering, is strictly limited to: citizens whose average family income is below the subsistence level, disabled children, orphans, children without parental care, etc. (Art. 20 of the Federal Law of November 21, 2011 No. 324-Ф3 On Free Legal Aid in the Russian Federation). Free legal aid to foreign citizens and stateless persons is provided in cases and in the manner prescribed by federal laws and international treaties of the Russian Federation.

Thus, when deciding on Russia's accession to the 2007 Convention, it is necessary to pay more attention to the problem of providing free legal assistance. On the one hand, in order to protect the rights of children to receive support from parents in relationships complicated by a foreign element, it seems fair to provide free legal assistance. On the other hand, there may be a violation of the principles of equality and non-discrimination in that part, in which a person living in Russia and applying for the recovering of alimony in its own territory, as a general rule, does not have the right to free legal aid. As a result, there is a difference in the application of the rules on free legal aid, based solely on the fact that relations are complicated by a foreign element. And despite the fact that paragraph 2 of Art. 15 of the Convention allows the State party to make a reservation on the refusal to provide free legal assistance in the event of a manifestly ill-founded claim, a. 16 allows you to declare providing free legal assistance only after checking the financial situation of the child, cannot apply to applications for recognition and / or enforcement of a decision regarding maintenance obligations arising from parent-child relationships for persons under the age of 21 .

\section{Summary}

When assessing the prospects of Russia's accession to the 2007 Convention, it is necessary to keep in mind both the presence of circumstances entailing a positive effect and contributing to the realization of the right to receive maintenance abroad, as well as factors that create certain difficulties and require changes in national legislation.

The presence in the Convention of a system of reservations and declarations can smooth out some contradictions (inconsistencies) between the provisions of the Convention and Russian law. In particular, a reservation seems necessary regarding the limitation of the age of a child entitled to alimony to 18 years. In addition, a reservation is possible in accordance with paragraphs. "C" p. 2, art. 20 of the Convention on the impossibility of recognition and enforcement of decisions adopted in the state of origin, on the grounds that the creditor has a place of residence in that state. It also seems possible to accept certain statements, especially regarding the application of the provisions of the Convention to maintenance obligations between spouses and other family members.

The most difficult to resolve the contradictions of the Convention and domestic law of Russia is the issue of providing free legal assistance. It seems that in order to better protect the rights and interests of the child in relations complicated by a foreign element, this issue should be resolved in accordance with Articles 15 and 16 of the Convention.

\section{Conclusion}

Taking into account the need to ensure the best interests of the child and fulfill its obligations as a country party to the UN Convention on the Rights of the Child, the ratification of the 2007 Convention seems appropriate for this and the relevant principles of the Decade of Childhood proclaimed in Russia.

\section{Acknowledgements}

The work is performed according to the Russian Government Program of Competitive Growth of Kazan Federal University.

\section{References}

Akhmetyanova, Z. A., Makarov, T. G., \& Nizamieva, O. N. (2018). Rights of Ownership of Minors from the Position of the Russian Law. Helix, 8(1), 2346-2351. https://doi.org/10.29042/2018-2346-2351

Borras, A., \& Degeling, J. (n.d.). The Convention of November 23, 2007 on the Interna-tional Recovery of Child Support and Other Forms of Family Maintenance: an explana-tory report. Retrieved from https://assets.hcch.net/upload/expl38.pdf

Civil Procedure Code of the Russian Federation. Federal Law of November 14, 2002 No. 138-FZ. Russian newspaper. 2002. November 20.

Family Code of the Russian Federation. Federal Law of December 29, 1995 No. 223-FZ. Russian newspaper. 1996.27 January.

Lopes, I. (2019). Chronicle 2 Cross-border Maintenance: an assessment after the Hague Convention entered into 
force in Brazil. Private International Law chronicles. Revista de Direito Internacional, Brasília, 16(1), 18-34. https://doi.org/10.5102/rdi.v16i1.6069

Problems of unification of private international law. ex. ed. A.L. Makovsky, I.O. Khlestova. M. 2013.

Reservations to international treaties: Guidelines for practice. adopted at the 63rd session of the UN General Assembly, $2008 . \quad$ Retrieved from https://www.un.org/en/documents/decl_conv/conventions/pdf/reservations_guidelines.pdf

Solomon-Fears, C., \& Smith, A. M. (2013). Hague Convention Treaty on Recovery of International Child Support and HR 1896. Congressional Research Service. Retrieved from https://fas.org/sgp/crs/row/R43109.pdf

Thorner, M. R., \& Huizinga, R. (2013). Hague Conference of the private international law - Work in 2013. Hague Yearbook of International Law. Annuaire de La Haye de Droit International, Vol. 26. Retrieved from https://books.google.com/books?id=J6clDwAAQBAJ\&pg

Trigubovich, N. V. (2016). To the question of the accession of the Russian Federation to the Convention on the international system for the recovery of alimony for children and other family members. Family and Housing Law, (6), 24.

UN Convention on the International Procedure for the Collection of Alimony for Children and Other Forms of Family Maintenance (The Hague, 11/23/2007): Status table of the Convention of November 23, 2007 on the International Recovery of Child Support and Other Forms of Family Maintenance. Retrieved from https://www.hcch.net/en/instruments/conventions/status-table/?cid=131

UN Convention on the Rights of the Child (New York, 11/20/1989). Retrieved from https://www.un.org/en/documents/decl_conv/conventions/childcon.shtml.

United Nations Convention on the Recovery of Alimony Abroad (New York, 06/20/1956). Retrieved from https://www.un.org/en/documents/decl_conv/conventions/childcon.shtml

\section{Copyrights}

Copyright for this article is retained by the author(s), with first publication rights granted to the journal.

This is an open-access article distributed under the terms and conditions of the Creative Commons Attribution license (http://creativecommons.org/licenses/by/4.0/). 